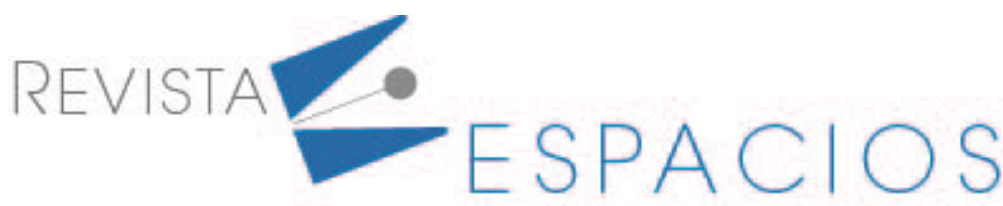

\title{
Restoration of the Rio Doce River Basin: a study on cooperation
}

\section{Restauración de la cuenca del río Doce: un estudio de cooperación}

SANTOS, Paulo H. ${ }^{1}$

\begin{abstract}
This research seeks to identify the development stage of the cooperation to manage the resources employed in the Rio Doce River Basin restoration, analyzing strategies for improving the results of such cooperation. This qualitative and quantitative descriptive research used semi-structured and structured interviews. The study applied a model of analysis of cooperative relations among agencies responsible for managing resources destined for the basin's restoration, identifying the cooperation's development stage.

Key words: cooperation, rio doce river basin, life cycle

Resumen

Esta investigación busca identificar la etapa de desarrollo en la que se encuentra la cooperación para el manejo de los recursos empleados en la restauración de la Cuenca del Río Doce, analizando estrategias para mejorar los resultados de dicha cooperación. Esta investigación descriptiva, cualitativa y cuantitativa, utilizó entrevistas estructuradas y semiestructuradas. El estudio aplicó un modelo de análisis de las relaciones de cooperación entre los organismos encargados de gestionar los recursos destinados a la restauración de la cuenca, identificando la etapa de desarrollo de la cooperación.

Palabras clave: cooperación, cuenca del río doce, ciclo de vida
\end{abstract}

\section{Introduction}

Although widespread worldwide, the interorganizational cooperation model is recent in Brazil (Wegner et al., 2015; Zancan et al., 2013).

The interest applying the perspective of networks on Brazilian organizational studies has substantially increased in the number of research and the quality of studies produced since the mid-2000s. Among other evidence, is volume 46 of Revista de Administração de Empresas (RAE), in 2006, and volume 43 of the Brazilian Journal of Public Administration (RAP), in 2009, focusing on networks. In addition, events coordinated by the National Association of Graduate Studies and Research in Administration (ANPAD) addressed this topic in six of its thematic areas, in 2011: Information Administration; Public Administration; Organizational Studies; Strategy in Organizations; Science, Technology, and Innovation Management; and Logistics Operations Management, thus

\footnotetext{
${ }^{1}$ Mestre em Engenharia de Produção e Sistemas. IFG - Instituto Federal de Goiás. Brasil. paulo.santos1@ifg.edu.br
} 
consolidating the significant growth of interest in the topic on the field of administration in Brazil (ZANCAN et al., 2013, pp. 650-651, our translation).

In Germany, for instance, there are around 200,000 businesses allied in over 320 business networks, representing an annual turnover of 350 billion euros (Veltmann, 2009). In Spain, there are 350 business networks comprising 46,000 small and medium-sized businesses, representing $7 \%$ of the country's gross domestic product (GDP) (Anceco, 2012). In developing countries such as Brazil, data point to a formation of around 800 business networks over the last decade (SEBRAE, 2008; RIO GRANDE DO SUL, 2010); but more updated studies reveal that many networks go inactive, or even close down activities, after just a few years in the market (Toigo and Alba, 2010; SEBRAE, 2012), suggesting that it is easier to start them than to take them to the mature stage.

Against this backdrop, it is necessary to create a model to describe the path of an interorganizational relation and represent the dysfunctions that can lead it - at any stage of the relation's development - to decline and dissolution (Wegner et al., 2014).

The life cycle model developed by Wegner et al. (2016) when studying small-firm networks (which they call SFNs) "contributes to overcome such theoretical gaps by taking into account SFNs characteristics and broadens the understanding of their changes over time" (Wegner et al. 2015, p. 41).

The proposal of a Small Firms Network (SFN) life cycle model is justified by a number of reasons. Life cycle models found in literature are mainly focused on strategic alliances (Jiang, Li, \& Gao, 2008; Spekman, Forbes, Isabella, \& Macavoy, 1998), client and supplier relationships (Zineldin, 2002) and partnerships. Such interorganizational agreements differ from SFNs in number of partners, governance and management. Moreover, existing models do not clearly represent which dimensions or characteristics of the cooperative agreement should be analyzed to understand its dynamics and development stages (Wegner et al., 2015, p. 41).

When creating the model, Wegner sought to understand each stage of the interorganizational relationships life cycle, analyzing seven dimensions that characterize this type of arrangement: management, governance, definition of processes and level of services offered, participants engagement and commitment, information exchange, trust, and interpersonal relationships (Wegner et al. 2014).

This research uses the life cycle model of cooperation relations, proposed by Wegner et al. (2016), to study an interorganizational cooperation in the State of Espírito Santo, based on the assumption that such cooperations go through different development stages. Each phase has different characteristics and requires specific governance, management, and coordination of interpersonal relations to achieve the collective objectives and cooperation advances throughout the consolidation process. In other words, it is possible to say that specific strategies are needed for each development stage of an interorganizational relationship (Wegner et al., 2015).

From the environmental perspective, there is a sharp and dangerous decrease in water reserves available on the planet. It is estimated that $40 \%$ of the world population today lives in regions where the annual water supply is less than 1,700 cubic meters per inhabitant, the minimum limit considered safe by the United Nations (UN).

If the current situation of consumption and degradation prevails, the prospects are not encouraging. By 2050, planet Earth is expected to have close to 9 billion inhabitants, and it is predicted that more than half of this total, 4.8 billion people, will live in a situation of water stress, while about 2 billion people will face water scarcity, according to the Washington-based International Food Policy Research Institute. Water scarcity is one of the most significant environmental challenges in the world, with more immediate impacts on human survival on Earth. Water is also the key to sustainable development globally and the main variable that drives the economy. The serious problem of decreasing water supply will immediately affect economic activities, generating serious conflicts with political implications in several nations (PIRH DOCE, 2010). 
In the Rio Doce River Basin, located in a region in the Brazilian states of Minas Gerais and Espírito Santo, the offer of water attracted many economic activities such as the steel industry mineral extraction, and agribusiness. However, the environmental damage from deforestation and fragmentation of native forests - causing erosion, silting, and degradation of the basin's springs and water resources - is a growing threat to the quality of life of 4 million people living in the area, and for the continuation of the economic activities, which are essential for the economy of the country as a whole. The water flow in the Rio Doce River Basin has been worryingly decreasing. For example, 40 years ago, the river was navigable in the state of Espírito Santo, between the municipalities of Regência and Mascarenhas $(143 \mathrm{~km})$. However, the reduction in water volume, the high sedimentation in its main canal, and other obstructions made navigation unfeasible. Studies point out that, by 2030, the water demand will be greater than the supply in some of Rio Doce's sub-basins. Affluents of middle and lower Rio Doce, currently perennial rivers, may become intermittent in less than 20 years (PIRH DOCE, 2010), and in some of the micro basins, conflicts over water use are already evident, mainly motivated by irrigation use.

In this context, the research question is: considering the stage of cooperation among the agencies that take part in strategic decision-making about resources for the restoration of the Rio Doce River Basin, what should be the strategies adopted to improve the results of such collaboration?

This article sought to identify the development stage of the cooperative relationships among the agencies managing the resources to restore the Rio Doce River Basin, analyzing strategies for improving such cooperation results. The specific objectives were to map the organizations present in the State of Espírito Santo involved in cooperation relationships to protect and restore Rio Doce; apply the life cycle model; identify the development stage of the selected organizations; analyze management and network strategies for the development of interorganizational cooperation.

This article helps managers to identify their interorganizational relation's development stage based on the characteristics observed. After identifying the aspects involved in each of the life cycle model stages, inductive actions will be established to develop absent characteristics, contributing to improve cooperative management efficiency. The dynamics of interorganizational relationships describe the relations' life cycle and contribute by offering an adequate model for analyzing this arrangement model. Based on this model, researchers and policymakers in Espírito Santo, and other Brazilian states, will be able to analyze interorganizational relations, devising more appropriate strategies for each partnership or connection.

The article starts with this introduction presenting a justification for the study and other particular aspects of the research, such as the originality and the logic that guided the investigation. The next section offers the theoretical reference, containing a summary of discussions found in the literature, building the ground to debate the development of the theme. The third section brings the methodology, presenting the research design, the sample size and selection, the materials and procedures used, the variables analyzed, and the analyses performed, revealing how the results were obtained, and enabling the search's applicability. The fourth section holds the analysis and discussion of results. Finally, the fifth section presents the conclusion.

\subsection{Life cycle of interorganizational cooperation networks}

Collaboration and democratic coordination guide the actions of actors involved in cooperation networks, which count on the participation of all parties engaged. According to Balestrin and Verschoore (2008, p. 98, apud Almeida and Silveira, 2015, p. 173, our translation), "the norms are specified in the association's bylaws and regime, representing stable but flexible contracts.".

The model by Wegner et al. (2016) offers six development stages for cooperation networks, which make up the life cycle. The stages are conception, birth and formalization, development, consolidation and maturity, decline, and dissolution (fig. 1). 
Figure 1

Cycle of interactions between stages and development in the life cycle model.

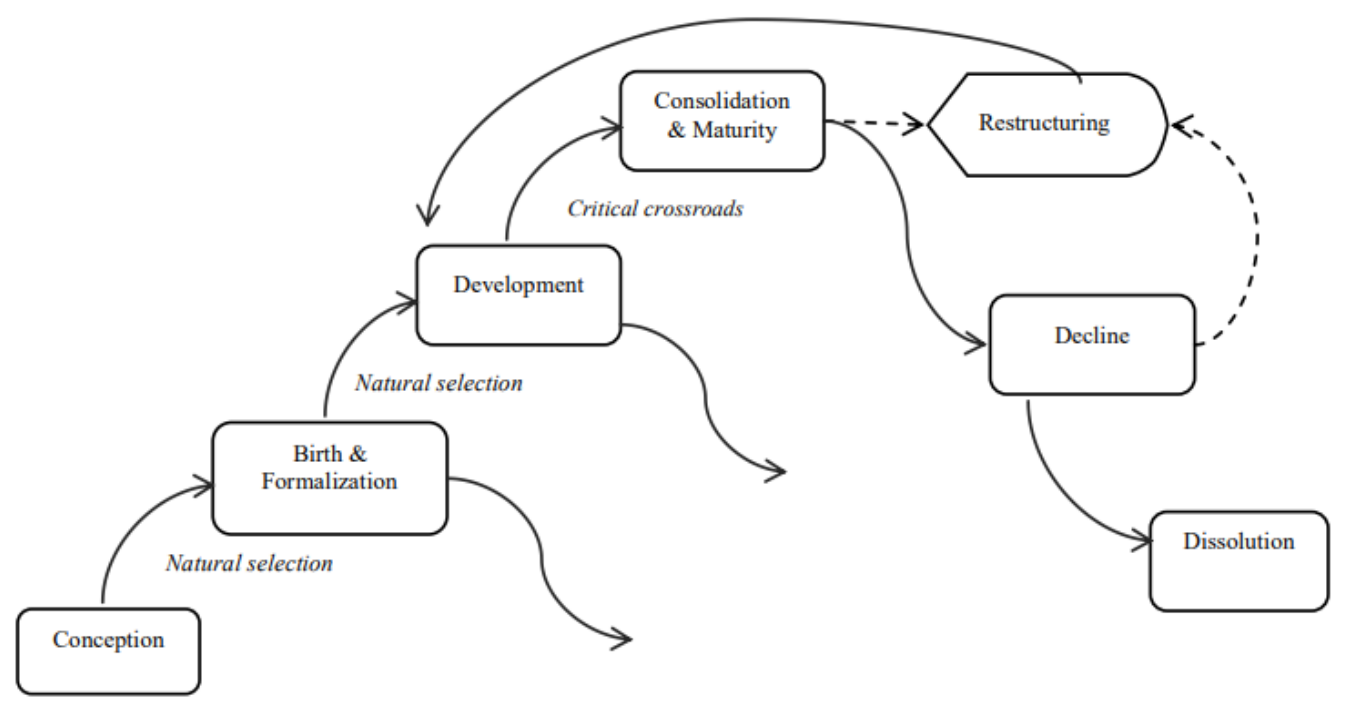

Source: Wegner et al. (2015) and Wegner et al. (2016).

Each stage must be discussed and clearly understood to fill the theoretical gaps in the life cycle model. This study searched the literature to support the discussion about each stage, identifying characteristics and aspects explored in the debates on the topic.

Table 1 -below- presents the description of the life cycle model stages, according to Wegner et al. (2015).

Table 1

Description of the life cycle model stages.

\begin{tabular}{|c|c|}
\hline Conception & $\begin{array}{l}\text { Entrepreneurs meet to discuss cooperation possibilities. The network governance is under } \\
\text { development. Entrepreneurs show a high level of participation in proposed activities and commitment } \\
\text { towards defined actions due to the state of motivation in relation to the potentialities of a collective } \\
\text { work. }\end{array}$ \\
\hline $\begin{array}{l}\text { Birth and } \\
\text { Formalization }\end{array}$ & $\begin{array}{l}\text { Networks of companies move from being just a project to being formalized by the members who define } \\
\text { a management board, executive councils, and work teams. The shared governance model is chosen, in } \\
\text { which the members themselves are responsible for the activities. }\end{array}$ \\
\hline Development & $\begin{array}{l}\text { The management structure and main processes have been defined and are adjusted in this stage, } \\
\text { resulting in improvements in the governance structure. Information and managerial experience can be } \\
\text { freely exchanged, which strengthens social relations within the group. }\end{array}$ \\
\hline $\begin{array}{l}\text { Consolidation } \\
\text { and Maturity }\end{array}$ & $\begin{array}{l}\text { Networks of companies take their management to a professional level, hiring an executive manager } \\
\text { and employees to manage activities. The elected board is responsible for strategic decisions. A network } \\
\text { administrative organization now runs the governance. A group of more engaged and committed } \\
\text { entrepreneurs stands out, while others take advantage of the benefits with little participation. }\end{array}$ \\
\hline Decline & $\begin{array}{l}\text { A lack of adjustments and improvements to the structures, processes, and governance leads to } \\
\text { discrediting amongst partners. Side groups appear with self-interests that try to influence management } \\
\text { and cause internal competition for power and space in the network management. Most entrepreneurs } \\
\text { prioritize sole action within their own firms instead of collective goals. }\end{array}$ \\
\hline Dissolution & $\begin{array}{c}\text { Although a management board may still be in place, it no longer manages the network. The networks } \\
\text { of companies experience neither structured management nor does it offer services. Governance rules } \\
\text { are no longer followed. Network members are no longer committed, and participation in the activities } \\
\text { is almost null. Most members leave the network, and only the ones strongly interested in cooperation } \\
\text { remain. }\end{array}$ \\
\hline
\end{tabular}

Source: Adapted from Wegner et al. (2015). 
Restructuring is a critical moment -but not an explicit stage- in the cooperation networks' life cycle. It is a necessary element to ensure that the network will last over time. Even though consolidated, the networks have to transform to avoid decline and dissolution. This need is justified by the change in resource bases, information bases, and members' expectations over time. In addition, companies continually expect higher levels of benefits from the network, even when they cannot obtain the proportional advantages of cooperation envisaged by collective strategies (Wegner et al., 2016).

Restructuring should occur soon after the cooperation network achieves the consolidation and maturity stage to keep it in consolidation. Likewise, it is necessary to pay attention to restructuring in the stages of decline, degeneration, and dissolution. Without restructuring, the cooperation network that reaches these last two stages may find itself being terminated (Wegner et al., 2015).

\section{Methodology}

\subsection{Research design}

The study was divided into three steps:

First step - Theoretical framework: the research is introduced, presenting the research question, objectives, justifications, and the theoretical background supporting the analyses.

Second step - Research development: the strategic guidelines and the methodological techniques and procedures are outlined.

Third step - Research analysis and results: the results are evidenced, carrying out an assessment of the cooperation relations studied. An analysis was conducted to obsderve the relations' development stage.

Fig. 2 shows these three steps, helping to understand how the research was conducted.

Figure 2

Research design
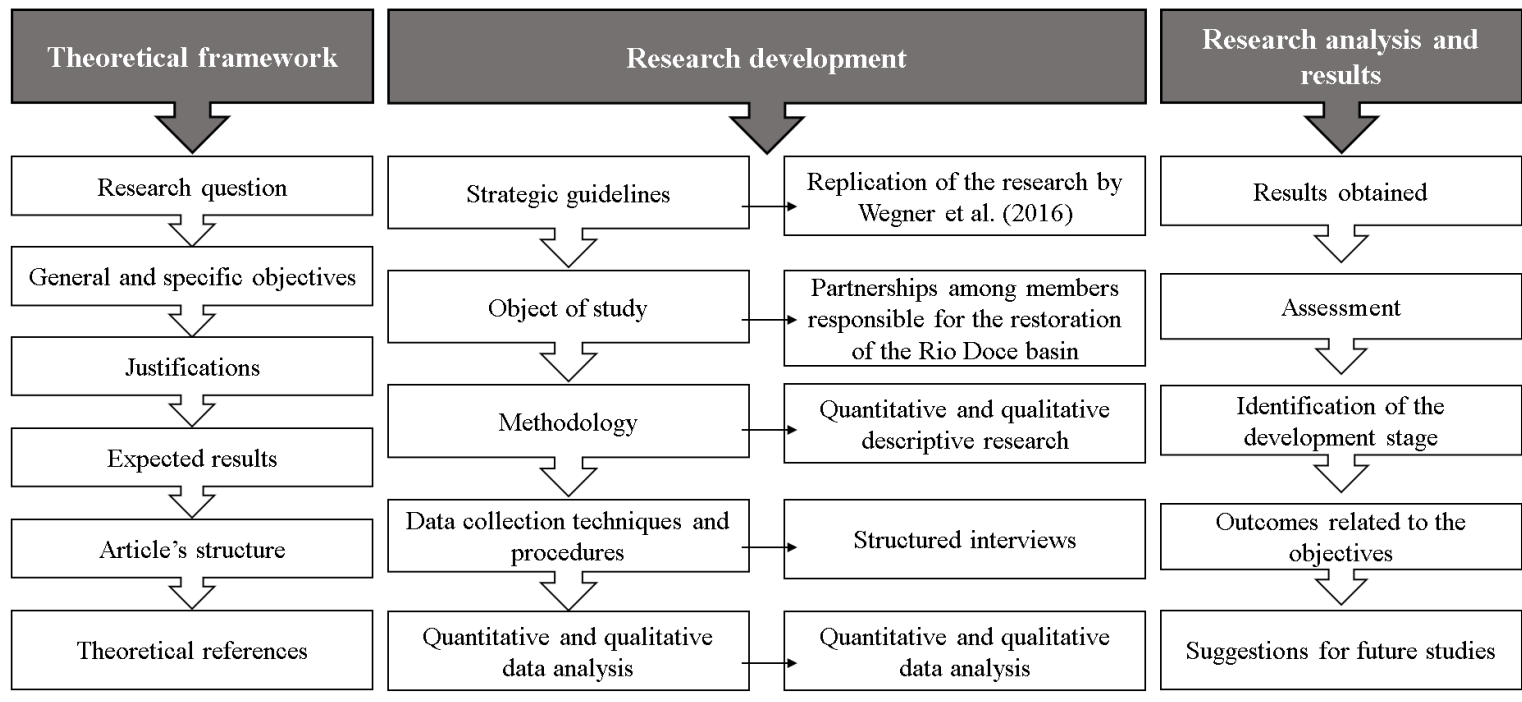

Source: Elaborated by the author, adapted from Estivalete (2007, p. 125)

\subsection{Strategic guidelines}

The research by Wegner et al. (2015) was carried out in two steps. The first was qualitative, conducted through interviews with experts, elaborating a version of the life cycle analysis model of cooperation networks. The second step consisted of applying the life cycle model in 28 networks of firms, established between 2000 and 
2012 and located in the regions of Vale do Rio Pardo and Vale do Taquari, in the Brazilian state of Rio Grande do Sul. The authors collected the data using a printed or electronic form. Each network's data were tabulated and analyzed separately, which allowed informing the network's development stage as defined with the contributions from the experts interviewed.

Using the model by Wegner et al. (2015), this study approached three members of the cooperation for the Rio Doce River Basin for a pilot test, selecting members that presented characteristics of different development stages, considering the stages elaborated based on the interviews with experts carried out by Wegner et al. (2015). The pilot test was conducted by different researchers of the work team in different geographic regions. It allowed adjusting the research dimensions or indicators according to their adequacy/inadequacy in the field.

This study follows some of the procedures adopted by Wegner et al. (2015) and focuses on agencies in the Brazilian state of Espírito Santo operating in partnership to restore the Rio Doce River Basin to assess the development stage of the cooperation.

\subsection{Research method}

The interviews with cooperating members were separated into two parts. The first part adopted a qualitative approach and was guided by a semi-structured script. Given that quality defines the nature of a phenomenon by elucidating its meaning, the qualitative approach allows better identification and understanding of the problem (MALHOTRA, 2005).

In the second part of the interview, the researcher applied the structured part of the questionnaire, which was descriptive and emphasized a qualitative and quantitative approach. Descriptive research aims for knowledge and interpretation of reality without modifying it, focused on discovering and interpreting the phenomena. This approach may be used as a basis to elucidate phenomena, but its emphasis is on revealing their characteristics without committing to explain them (VIEIRA, 2002).

For Perin et al. (2015), descriptive research maps the distribution of a phenomenon in a given population. In general, it seeks to determine the frequency of the occurrence of something or the relationship among variables that are usually guided by an initial hypothesis.

From the methodological point of view, the qualitative and quantitative approaches are not contradictory or continuous, but they have a different nature. These methods are used individually to conduct empirical studies with different characteristics. They refer to the quality of the data obtained, the possibilities of obtaining them, and how they are used and analyzed. Qualitative questions are usually asked to achieve quantitative results (Luz and Azevedo, 2015). This was the case in this study, where qualitative questions were submitted to interviewees in order to achieve quantitative results.

According to Silva et al. (2017), quantitative research seeks the validation of hypotheses through structured data, analyzing representative cases. This orientation of quantitative research was used to quantify the data and generalize results.

\subsection{Interviewees' selection}

The interviewees' selection was conducted as suggested by Flick (2009), who stresses the importance of selecting people who have great knowledge about the topic of interest and, preferably, bring different points of view. After defining the cooperation relations as the unit of analysis, the data collection was carried out with members and representatives of the agencies cooperating for the restoration of the Rio Doce River Basin. 


\subsection{Data collection techniques and procedures}

As mentioned before, interviews were conducted in two parts, starting with a semi-structured qualitative questionnaire, followed by a qualitative and quantitative structured questionnaire.

The semi-structured interviews were carried out in person and recorded on an audio device and later transcribed. These interviews lasted 60 minutes each.

The structured interviews were conducted in person and via phone calls. Interviewees took around 15 minutes to answer all the questions.

The semi-structured script adopted in the first part of the interviews was built based on business cooperation and business network development literature. At the beginning of the interview, participants were asked about their experience on the topic, followed by questions exploring their opinion about what stage best reflected the life cycle of cooperative relationships among the agencies involved in the restoration of the Rio Doce River Basin, and what dimensions the interviewees believe were relevant to identify such development stage.

Based on the outcomes obtained by Wegner et al. (2015) when consulting experts, the research explored the dimensions that would contribute to analyze and identify the cooperation's development stage.

The data collection protocol was based on three aspects, governance, information exchange, and leadership.

The interviewees were asked about the current status of the partnership regarding these three aspects and about changes that have occurred in their network over time in each of the aspects.

The data were tabulated and analyzed based on each network, individually, generating information that allowed - with the specialists' participation - to frame the relationship for the development stage.

The interviews were planned to reach the largest number of partners in the Brazilian state of Espírito Santo, as a way of delineating the interviewees, as the main objective of the research was to understand the life cycle of the interorganizational relationships located in the state and engaged in restoring the Rio Doce River Basin. This part of the interviews was planned to be in-person. However, the difficulty in organizing the interviewees' schedules and contacting the managers led the author to conduct the interviews via telephone and applications.

The interviewees' information - names, agencies, and positions - was collected beforehand on the agencies' websites. After identifying the interviewees, they were contacted via phone and application.

\section{Analysis of Results and Discussion}

Table 2 shows the aspect 'governance' explored in the interview with the network's members.

Table 2 shows that $78 \%$ of the interviewees agree that cooperation has well-defined strategic processes, and $67 \%$ agree that members are allowed to attend the process of making strategic decisions. When asked whether the process favors the members' participation in decision-making, 33\% of members neither agree nor disagree, and $33 \%$ agree. The formalization of rights and duties is an aspect recognized by the interviewees (67\% agree). As for the aspects where the interviewees do not entirely agree, controlling whether members are complying with all established rules stood out, where $56 \%$ neither agree nor disagree. Regarding the statement about the system of rewards and incentives to follow the rules and the statement on the application of sancitons and punishments, both presented $44 \%$ of interviewees who neither agree nor disagree. 
Table 2

Aspect - Governance

\begin{tabular}{|c|c|c|c|c|c|}
\hline About GOVERNANCE: & (1) Disagree & $\begin{array}{l}\text { (2) Partially } \\
\text { disagree }\end{array}$ & $\begin{array}{l}\text { (3) Neither } \\
\text { agree nor } \\
\text { disagree }\end{array}$ & $\begin{array}{l}(4) \\
\text { Partially } \\
\text { agree }\end{array}$ & $\begin{array}{l}(5) \\
\text { Agree }\end{array}$ \\
\hline $\begin{array}{l}\text { Members establish a process defining who } \\
\text { participates in strategic decisions and how they are } \\
\text { made (strategic decisions are those that affect the } \\
\text { future of the network in the coming years). }\end{array}$ & $0 \%$ & $0 \%$ & $11 \%$ & $78 \%$ & $11 \%$ \\
\hline $\begin{array}{l}\text { Members are allowed to attend the process of } \\
\text { making the networks' strategic decisions (those } \\
\text { that affect its future in the coming years). }\end{array}$ & $0 \%$ & $0 \%$ & $22 \%$ & $11 \%$ & $67 \%$ \\
\hline $\begin{array}{l}\text { The process of making the networks' strategic } \\
\text { decisions favors the participation of all members }\end{array}$ & $11 \%$ & $11 \%$ & $33 \%$ & $33 \%$ & $11 \%$ \\
\hline $\begin{array}{l}\text { The members' rights and duties are sufficiently } \\
\text { formalized and detailed in documents and bylaws. }\end{array}$ & $0 \%$ & $0 \%$ & $0 \%$ & $67 \%$ & $33 \%$ \\
\hline $\begin{array}{l}\text { Members have a rewards and incentives system } \\
\text { for those who follow the rules. }\end{array}$ & $11 \%$ & $22 \%$ & $44 \%$ & $22 \%$ & $0 \%$ \\
\hline $\begin{array}{l}\text { Adequate sanctions and punishments are applied } \\
\text { to members who do not comply with the rules. }\end{array}$ & $22 \%$ & $22 \%$ & $44 \%$ & $11 \%$ & $0 \%$ \\
\hline $\begin{array}{l}\text { Members have ways of controlling whether they } \\
\text { are complying with the rules. }\end{array}$ & $0 \%$ & $11 \%$ & $56 \%$ & $33 \%$ & $0 \%$ \\
\hline
\end{tabular}

For Silva and Neves (2013) and Jacobson (2015), network governance is complex due to the challenges of finding the balance between cooperation and competition, with no generic application.

According to Provan and Kenis (2007, p. 231), "governance is necessary to ensure that participants engage in collective and mutually supportive action, that conflict is addressed, and that network resources are acquired and utilized efficiently and effectively".

Table 3 presents the aspect of 'information exchange' in the interviews conducted with members.

The information exchange aspect in Table 3 shows that $44 \%$ of the members neither agree nor disagree about the existence of a high level of information exchange among members. Also, 33\% neither agree nor disagree that the information is important for the partners. It is noteworthy that the partnership security and stability stimulate information exchange among members (Tureta and Paç-Cunha, 2006).

When the integration process evolves, communication barriers among participants are broken, opening space for continuous exchange of technical information that benefits everyone (Toigo and Alba, 2010).

The majority of members (67\%) agree that the office offers a large amount of relevant information to members. Zabotto et al. (2014) list examples of information that can be made available in these cases, such as structure/team, problems, procedures and methods, analysis of data, experience with consulting companies, internally developed methods, participation in events, costs, process development, briefing models, report templates, market research, a database for recruitment. 
Table 3

Aspect - Information exchange

\begin{tabular}{|c|c|c|c|c|c|}
\hline About INFORMATION EXCHANGE: & (1) Disagree & $\begin{array}{l}\text { (2) Partially } \\
\text { disagree }\end{array}$ & $\begin{array}{l}\text { (3) Neither } \\
\text { agree nor } \\
\text { disagree }\end{array}$ & $\begin{array}{l}\text { (4) } \\
\text { Partially } \\
\text { agree }\end{array}$ & $\begin{array}{l}(5) \\
\text { Agree }\end{array}$ \\
\hline $\begin{array}{l}\text { There is a high level of information exchange } \\
\text { among the members (about management, } \\
\text { suppliers, strategies). }\end{array}$ & $22 \%$ & $11 \%$ & $44 \%$ & $11 \%$ & $11 \%$ \\
\hline $\begin{array}{l}\text { The office (or equivalent) offers a great deal of } \\
\text { information to members. }\end{array}$ & $0 \%$ & $0 \%$ & $11 \%$ & $22 \%$ & $67 \%$ \\
\hline $\begin{array}{l}\text { The information exchanged is highly important for } \\
\text { the partners. }\end{array}$ & $11 \%$ & $22 \%$ & $33 \%$ & $22 \%$ & $11 \%$ \\
\hline
\end{tabular}

Table 4 presents the 'leadership' aspect of the interview.

Table 4

Aspect - Leadership

\begin{tabular}{|c|c|c|c|c|c|}
\hline About the LEADERS: & (1) Disagree & $\begin{array}{l}\text { (2) Partially } \\
\text { disagree }\end{array}$ & $\begin{array}{l}\text { (3) Neither } \\
\text { agree nor } \\
\text { disagree }\end{array}$ & $\begin{array}{l}\text { (4) } \\
\text { Partially } \\
\text { agree }\end{array}$ & $\begin{array}{c}(5) \\
\text { Agree }\end{array}$ \\
\hline $\begin{array}{l}\text { Active leaders guide the partnerships' } \\
\text { development. }\end{array}$ & $0 \%$ & $11 \%$ & $11 \%$ & $56 \%$ & $22 \%$ \\
\hline $\begin{array}{l}\text { There is an encouragement to prepare new leaders } \\
\text { to guide the network in the future (lead teams, } \\
\text { tasks, projects, or take on board positions). }\end{array}$ & $0 \%$ & $33 \%$ & $56 \%$ & $11 \%$ & $0 \%$ \\
\hline There is leadership turnover in partnerships. & $0 \%$ & $0 \%$ & $22 \%$ & $22 \%$ & $56 \%$ \\
\hline There are no disputes over leadership. & $11 \%$ & $44 \%$ & $33 \%$ & $11 \%$ & $0 \%$ \\
\hline
\end{tabular}

Table 4 shows that $56 \%$ of the interviewees agree that there is a turnover of leaders on board member and team coordination positions, and the same percentage agree that active leaders guide the partnerships' development. Table 4 also suggests disputes over leadership, as $44 \%$ of members disagree that there are no disputes over leadership in the network. As for encouragement to prepare new leaders, $56 \%$ of interviewees answered that they neither agree nor disagree about such a stimulus from the acting leaders.

The cooperation relationship among members of partnerships that share the goal of restoring the Rio Doce River Basin was considered in the Maturity/Consolidation phase.

The semi-structured interview shows some important points that highlight the assessment about the development stage in the life cycle model developed by Wegner et al. (2013), such as marketing projects and award projects, periodic meetings among members, administrative organization, high confidence level, welldefined structure, clear and well-defined rules.

\section{Conclusions}

The research result demonstrated that those involved were included in the Maturity/Consolidation stage, characterized by achieving stability and developing a set of activities that meet the participants' needs.

The importance of external influence on cooperation stood out, originated from partners, the government, other experiences, universities, consultants, and research involving this type of organization. 
The research did not observe the union between agencies operating in the state of Espírito Santo. However, one important point was the informal exchange of information among members through applications and social networks.

This study contributes to the field in several ways. From a theoretical point of view, it contributes to filling gaps related to the dynamics of cooperation between partners and the management of cooperation. From a managerial point of view, it serves as a basis for managers of partner entities that need a better understanding of the development stage of the cooperative arrangement, in the same way, assisting them in necessary actions for consolidation. From the point of view of regional development, it is an efficient mechanism for preserving or developing cooperative relationships between those involved in causes that benefit the environment and regions devastated by disasters. Finally, from the point of view of public management, it can generate relevant information for the elaboration of more effective public policies.

Some of the difficulties experienced during the research included: lack of access to institutional information from the agencies responsible for resource management, non-collaboration of some of those selectable for an interview with information relevant to the study, non-authorization to disclose the names of the agencies responsible for the management of resources destined to the restoration of the Rio Doce River Basin. Finally, the COVID-19 pandemic during the research brought certain restrictions, which caused great difficulty collecting information face-to-face.

Future research for the continuation of this study could include its replication in other regions of the country, more in-depth scientific investigations on the life cycle model, studies aimed at understanding the detailed dynamics of the cooperation stages to improve management. In addition, further research should focus on prolonging and qualifying the cooperation and explore, within this line of research around the cooperations' life cycle, topics such as leadership in the institutions participating in the cooperation, decisions based on each stage of the cycle, and experiences of merging entities collaborating to achieve a common goal.

\section{Acknowledgments}

We are grateful for the financial support received from the Espírito Santo Science and Technology Support Foundation - FAPES, obtained through the FAPES grant \#21/2018-universal.

\section{Bibliographic references}

ALMEIDA, G. G. F., \& SILVEIRA, R. L. L. (2015). Redes de cooperação e Território: o caso da Associação Rede Casanova. Desenvolvimento em Questão, v. 13, n. 29, p. 158-190. DOI: 10.21527/2237-6453.2015.29.158190

ANCECO. (2012). Asociación Nacional de Centrales de Compra y Servicios. Site institucional. Retrieved from: >http://www.anceco.com<

ESTIVALETE, V. F. B. (2007). O Processo de Aprendizagem em Redes Horizontais do elo Varejista do Agronegócio: do nível individual ao interorganizacional. PhD Dissertation, Federal University of Rio Grande do Sul, Porto Alegre. Retrieved from: http://hdl.handle.net/10183/10031

FLICK, U. An introduction to qualitative research. Sage, 2009. Retrieved from: https://uk.sagepub.com/engb/eur/an-introduction-to-qualitative-research/book261109

JACOBSON, D. D. (201516). How and why network governance evolves: evidence from a public safety network. Electronic Markets, v. 26, n. 1, p. 43-54. Retrieved from:

https://link.springer.com/article/10.1007/s12525-015-0203-0 
JIANG, X.; LI, Y.; GAO, S. (2008). The stability of strategic alliances: Characteristics, factors and stages. Journal of International Management, v. 14, n. 2, p. 173-189. DOI: 10.1016/j.intman.2007.09.002

LUZ, L. K. M., \& AZEVEDO, G. R. (2015). Avaliação de um programa de capacitação de agentes comunitários de saúde. Revista da Faculdade de Ciências Médicas de Sorocaba, v. 17, n. 4, p. 193-198. Retrieved from: https://revistas.pucsp.br/index.php/dic/article/view/16471

MALHOTRA, N. K. (2005). Introdução à pesquisa de marketing. São Paulo: Pearson Prentice Hall. Retrieved from: https://loja.grupoa.com.br/introducao-a-pesquisa-de-marketing9788587918772-p1005242

PERIN, M. G.; SAMPAIO, C. H.; FROEMMING, L. M. S. \& LUCE, F. B. (2015). Pesquisa survey em artigos de marketing nos ENANPADs da década de 90. Revista Interdisciplinar de Marketing, v. 1, n. 1, p. 44-59. DOI: 10.4025/rimar.v1i1.26257

PIRH DOCE. (2010). Plano Integrado de Recursos Hídricos da Bacia do Rio Doce e dos Planos de Ações de Recursos Hídricos para as Unidades de Planejamento e Gestão de Recursos Hídricos no Âmbito da Bacia do Rio Doce. Volume I - Relatório Final. CONSÓREDE DE COOPERAÇÃOO ECOPLAN - LUME. Retrieved from: http://www.cbhdoce.org.br/pirh-parh-pap/pirh

PROVAN, K. G., \& KENIS, P. (20087). Modes of network governance: Structure, management, and effectiveness. Journal of public administration research and theory, v. 18, n. 2, p. 229-252. DOI: 10.1093/jopart/mum015

SEBRAE - Serviço Brasileiro de Apoio às Micro e Pequenas Empresas. Mapeamento das centrais e redes de negócio. 2008. Retrieved from: >http://www.sebrae.com.br/customizado/acesso-amercados/sebraemercado/<

SEBRAE - Serviço Brasileiro de Apoio às Micro e Pequenas Empresas. (2008). Mapeamento das centrais e redes de negócio. Retrieved from: https://bibliotecas.sebrae.com.br/chronus/ARQUIVOS_CHRONUS/bds/bds.nsf/bbd21992b374f738f45145 7a96b70aad/\$File/6029.pdf

SEBRAE - Serviço Brasileiro de Apoio às Micro e Pequenas Empresas. (2012). Mapeamento das centrais e redes de negócio. Retrieved from: http://www.bibliotecas.sebrae.com.br/chronus/ARQUIVOS_CHRONUS/bds/bds.nsf/65d554f58cf2ffac0853 65d041699b02/\$File/5188.pdf

SILVA, E. K. S.; DE FIGUEIREDO, L. V., \& DA SILVA, E. L. (2017). Banco internacional de objetos educacionais: caracterização dos objetos virtuais de aprendizagem disponibilizados para docência em química analítica. Revista de Pesquisa Interdisciplinar, v. 1, n. Esp. DOI: 10.24219/rpi.v1iEsp.83

SILVA, G. M., \& NEVES, J. A. B. (2013). Divisão do trabalho social e arranjos produtivos locais: reflexos econômicos de efeitos morais de redes interorganizacionais. Revista de Administração Mackenzie, v. 14, n. 1, p. 202. DOI: 10.1590/S1678-69712013000100009

SPEKMAN, R.E.; FORBES, T.M.; ISABELLA, L.A.; MACAVOY, T.C. (1998). Alliance management: a view from the past and a look to the future. Journal of Management Studies, v. 35, n. 6, p. 747-772. DOI: 10.1111/14676486.00118

TOIGO, T., \& ALBA, G.R. (2010). Programa Redes de Cooperação do Estado do Rio Grande do Sul: Perfil das Redes de Empresas Acompanhadas pela Universidade de Caxias do Sul. XIII Semead - Seminários em Administração. Anais. São Paulo, Edusp. Retrieved from: http://sistema.semead.com.br/13semead/resultado/trabalhosPDF/510.pdf 
TURETA, C., \& PAÇO-CUNHA, E. (2010). Emergência e constituição de redes interorganizacionais de pequenas e médias empresas: Um estudo de caso no contexto brasileiro. GESTÃO. Org-Revista Eletrônica de Gestão Organizacional, v. 6, n. 1. DOI: 10.51359/1679-1827.2008.21615

ZANCAN, C., \& CRUZ, N. J. T. (2013). Mecanismos de Coordenação na Formação de Redes de cooperação: Associação dos Produtores de Vinhos Finos do Vale dos Vinhedos. Revista de Ciências da Administração, v. 15, n. 36, p. 193. DOI: 10.5007/2175-8077.2013v15n36p193VELTMANN, L. (2009). Eckpfeiler des Erfolgs im Mittelstand. Verbundgruppe \& Kooperation. Retrieved from: >https://eur-lex.europa.eu/legalcontent/DE/TXT/PDF/?uri=OJ:C:2010:087E:FULL\&from=SL<

VIEIRA, V. A. (2002). As tipologias, variações e características da pesquisa de marketing. Revista da FAE, Curitiba, v. 5, n. 1, p. 61-70. Retrieved from: https://revistafae.fae.edu/revistafae/article/view/449

WEGNER, D.; ALIEVI, R., \& BEGNIS, H. S. M. (2013). O Ciclo de Vida das Redes Empresariais: Uma avaliação do estágio de desenvolvimento de redes no Sul do Brasil. XVI SEMEAD Seminários em Administração. October. Retrieved from: http://sistema.semead.com.br/16semead/resultado/trabalhosPDF/487.pdf

WEGNER, D.; BEGNIS H. S. M., \& ALIEVI R. M. (2015). The Life Cycle of Small-firm Networks: An Evaluation of Brazilian Business Networks. Brazilian Administration Review, v-12, p-39-62. DOI: 10.1590/18077692 bar2015140030

WEGNER, D.; BEGNIS H. S. M.; ALIEVI R. M., \& MAEHLER A. E. (2016). The dynamics of cooperation: proposal of a life cycle model of small-firm networks. Gestão Regionalidade, v- 32, n. 94. DOI:

10.13037/gr.vol32n94.2805

WEGNER, D.; DE ROSSI, G., \& SCARANO, T. F. (2014). A dinâmica da cooperação: um estudo longitudinal em redes empresariais do setor moveleiro. Contextus-Revista Contemporânea de Economia e Gestão, v. 12, n. 1, p. 111-137. DOI: 10.19094/contextus.v12i1.32173

ZABOTTO, C. N.; SILVA, S. L., \& TORKOMIAN, A. L. V. (2014). Um estudo de redes de usabilidade de produtos: Aprendizados para a cooperação empresarial. Perspectivas em Gestão \& Conhecimento, v. 4, p. 83-95. Retrieved from: http://hdl.handle.net/20.500.11959/brapci/51255

ZANCAN, C. S.; COSTA, P. D. C., \& DA CRUZ S. N. J. T. (2013). Condicionantes de consolidação de redes de cooperação interorganizacional: um estudo de caso sobre o Rio Grande do Sul. Revista de Administração Pública, v. 47, n. 3, p. 647-669. DOI: 10.1590/S0034-76122013000300006

ZINELDIN, M. (2002). Developing and managing a romantic business relationship: life cycle and strategies. Managerial Auditing Journal, v. 17, n. 9. p. 546-558. DOI: 10.1108/02686900210447542

Esta obra está bajo una Licencia Creative Commons Attribución-NoCommercial 4.0 International

(cc) EY-NC 